\title{
Effect of Vitamin A against Methotrexate-Induced Damage to the Small Intestine in Rats
}

\author{
Mehmet Yüncü a Ayhan Eralpa ${ }^{a}$ Mehmet Koruk $^{b}$ Ibrahim Saric \\ Cahit Bağcid Serap Inalöz ${ }^{\text {a }}$
}

Departments of a Histology and Embryology, ${ }^{b}$ Gastroenterology, cPathology, and dPhysiology, Gaziantep University Medical School, Gaziantep, Turkey

\author{
Key Words \\ Methotrexate $\cdot$ Intestine $\cdot$ Vitamin A
}

\begin{abstract}
Objective: The aim of the present study was to examine whether or not the administration of vitamin A (VA) protects against methotrexate (MTX)-induced damage to small intestinal epithelium. Materials and Methods: Sixty-three male Wistar albino rats, 10-12 weeks old, weighing 240-280 g, were divided into three groups: (1) controls, (2) rats receiving MTX treatment alone, and (3) rats receiving MTX plus VA treatment. A single dose of MTX ( $20 \mathrm{mg} / \mathrm{kg}$ MTX in $20 \mathrm{ml}$ vehicle) was administered to the rats intraperitoneally. For MTX plus VA treated groups, retinol palmitate (VA) 5,000 IU/kg dissolved in $0.5 \mathrm{ml}$ sunflower oil was administered by intragastric tube 3 days prior to MTX treatment and continued till the rats were sacrificed. The control group was treated with vehicle. Both control and MTX-alone groups were also treated with sunflower oil as a placebo. The rats were sacrificed on the 2nd, 4th and 6th day after MTX treatment. Tissue samples from the jejunum were taken for histopathological analysis. Results: MTX treatment induced villus shortening and fusion, epithelial atrophy, crypt loss, inflammatory infiltrate in the lamina propria, and goblet cell depletion. The pre- and post-treatment administra-
\end{abstract}

tion of VA decreased the severity of jejunal damage caused by MTX treatment. Conclusion: Our results confirmed that administration of VA decreased the MTXinduced damage to the small intestine. This protective effect of VA may have clinical applications in cancer chemotherapy.

Copyright $@ 2004$ S. Karger AG, Basel

\section{Introduction}

The occurrence of severe toxicity associated with cancer therapy is a serious consideration when choosing cancer chemotherapy options. Methotrexate (MTX) is an anticancer drug that has been shown to be highly effective against various malignancies [1]. The antimitotic effect of MTX is known to give rise to the malabsorption syndrome [2-4] that decreases the surface area for absorption caused by histological alterations such as shortened microvilli, resulting in less absorption of nutrients [5]. In addition, MTX depresses absorption of certain drugs from the small intestine [5], metabolic activity and active transport capacity of the intestinal mucosa [6]. It also decreases the brush border membrane protein and lipid contents of the small intestine [5,7] and inhibits the enzyme dihydrofolate reductase, which is required for DNA synthesis and cell division [8,9]. These adverse

\begin{tabular}{ll}
\hline KARGER & ( ) 2004 S. Karger AG, Basel \\
Fax +4161306 1234 & 1011-7571/04/0136-0346\$21.00/0 \\
$\begin{array}{l}\text { E-Mail karger@karger.ch } \\
\text { www.karger.com }\end{array}$ & $\begin{array}{l}\text { Accessible online at: } \\
\text { www.karger.com/mpp }\end{array}$
\end{tabular}

Doç. Dr. Mehmet Yüncü

Gaziantep Üniversitesi Tıp Fakültesi

Histoloji ve Embriyoloji Anabilim Dalı

TR-27310 Gaziantep (Turkey)

Tel. +90 3423606060 7781, Fax +90 342 3601617, E-Mail yuncu@gantep.edu.tr 
effects of MTX on the small intestine possibly result from the inhibition of intestinal epithelial cell turnover following damage to crypt cells $[10,11]$. Hence, various regimens for MTX chemotherapy have been tried to reduce the side effects. A high-dose MTX regimen with leucovorin rescue has been recommended as a useful regimen [12, $13]$.

Vitamin A (VA) is essential for normal growth and differentiation of epithelial tissues [14]. In several studies, it has been shown that VA may directly regulate intestinal epithelial cell proliferation and regeneration $[15,16]$. Zile et al. [15] suggested that VA deficiency causes an increase in the length of the S2 phase of the rat jejunal crypt cell cycle. VA deficiency has long been recognized to have a deleterious effect on epithelial tissues causing disruption of normal cellular differentiation. It has been suggested that VA coadministration prevents MTX-induced decrease in the contents of the small intestinal membrane protein and lipid, and preserves partly the activity of thymidine kinase, which is a key enzyme in the salvage pathway of DNA synthesis [7, 17, 18].

The aim of this study was to examine whether or not administration of VA has a protective effect against MTX-induced injury to the small intestine.

\section{Materials and Methods}

\section{Experimental Model}

In this study, 63 male Wistar albino rats 10-12 weeks old, weighing 240-280 g, were used. All the rats were housed in a single room in steel cages. The rats were housed 5 or 6 per cage $(42 \mathrm{~cm} \times 26 \mathrm{~cm})$ and maintained on a 12-hour light/dark cycle (change performed at 6.00 and $18.00 \mathrm{~h}$ ), at a constant temperature of $21 \pm 2{ }^{\circ} \mathrm{C}$ and relative humidity of $50-70 \%$. The rats were divided into three groups: (1) a control group $(\mathrm{n}=15),(2)$ rats receiving MTX alone $(\mathrm{n}=24)$, and (3) rats receiving MTX plus VA $(n=24)$. This study was approved by the ethics committee of Gaziantep University Medical Faculty.

Table 1. Weight loss in experimental animals following treatment with MTX alone or MTX plus VA

\begin{tabular}{lccc}
\hline Group & Day 2 & Day 4 & \multicolumn{1}{c}{ Day 6 } \\
\hline Control & $-0.34 \pm 1.38$ & $-0.30 \pm 1.35$ & $0.70 \pm 1.52$ \\
MTX-treated & $8.38 \pm 2.77^{\mathrm{a}}$ & $11.13 \pm 2.10^{\mathrm{b}}$ & $17.37 \pm 4.07^{\mathrm{c}}$ \\
$\begin{array}{c}\text { MTX plus } \\
\quad \text { VA-treated }\end{array}$ & $4.63 \pm 2.45^{\mathrm{a}}$ & $5.25 \pm 2.25^{\mathrm{b}}$ & $6.25 \pm 1.91^{\mathrm{c}}$ \\
\hline
\end{tabular}

The weight loss in MTX plus VA-treated rats was less than that in MTX-treated rats.

${ }^{\mathrm{a}} \mathrm{p}<0.05 ;{ }^{\mathrm{b}} \mathrm{p}<0.01 ;{ }^{\mathrm{c}} \mathrm{p}<0.001$.
Table 2. Scores (arithmetical means $\pm \mathrm{SD}$ ) in the small intestine of rats on days 2,4 and 6 following treatment with MTX alone or MTX plus VA

\begin{tabular}{lllll}
\hline Parameter & $\begin{array}{l}\text { Control } \\
\text { group } \\
(\mathrm{n}=5)\end{array}$ & $\begin{array}{l}\text { MTX-treated } \\
\text { group } \\
(\mathrm{n}=8)\end{array}$ & $\begin{array}{l}\text { MTX + VA- } \\
\text { treated group } \\
(\mathrm{n}=8)\end{array}$ & \\
\hline Day 2 & & & & \\
Villous damage & $0.0 \pm 0.0$ & $1.75 \pm 0.46$ & $1.13 \pm 0.64$ & $<0.001$ \\
Crypt damage & $0.0 \pm 0.0$ & $1.88 \pm 0.64$ & $1.25 \pm 0.46$ & $<0.001$ \\
Cellular infiltration & $0.2 \pm 0.4$ & $1.13 \pm 0.64$ & $0.50 \pm 0.53$ & $<0.05$ \\
Goblet cell depletion & $0.0 \pm 0.0$ & $1.88 \pm 0.64$ & $1.50 \pm 0.53$ & $<0.001$ \\
Total score of small intestinal damage & $0.2 \pm 0.4$ & $6.63 \pm 2.20^{\mathrm{a}}$ & $4.38 \pm 1.92^{\mathrm{a}}$ & $<0.05$ \\
\hline Day 4 & & & & \\
Villous damage & $0.0 \pm 0.0$ & $2.38 \pm 0.74$ & $1.75 \pm 0.71$ & $<0.001$ \\
Crypt damage & $0.0 \pm 0.0$ & $2.63 \pm 0.52$ & $1.88 \pm 0.64$ & $<0.001$ \\
Cellular infiltration & $0.4 \pm 0.5$ & $2.75 \pm 0.46$ & $1.63 \pm 0.74$ & $<0.001$ \\
Goblet cell depletion & $0.2 \pm 0.4$ & $2.50 \pm 0.76$ & $1.88 \pm 0.64$ & $<0.005$ \\
Total score of small intestinal damage & $0.6 \pm 0.9$ & $10.25 \pm 2.31^{\mathrm{b}}$ & $7.12 \pm 2.59^{\mathrm{b}}$ & $<0.01$ \\
\hline Day 6 & & & & \\
Villous damage & $0.2 \pm 0.4$ & $1.75 \pm 0.46$ & $1.38 \pm 0.52$ & $<0.005$ \\
Crypt damage & $0.2 \pm 0.4$ & $1.63 \pm 0.52$ & $1.13 \pm 0.64$ & $<0.01$ \\
Cellular infiltration & $0.2 \pm 0.4$ & $2.50 \pm 0.76$ & $1.63 \pm 0.74$ & $<0.005$ \\
Goblet cell depletion & $0.2 \pm 0.4$ & $1.88 \pm 0.64$ & $1.25 \pm 0.46$ & $<0.005$ \\
Total score of small intestinal damage & $0.8 \pm 1.6$ & $7.75 \pm 2.19^{\mathrm{c}}$ & $5.38 \pm 2.20^{\mathrm{c}}$ & $<0.05$ \\
\hline & & & & \\
\hline
\end{tabular}

The severity of intestinal tissue damage in MTX plus VA-treated rats was less than that in MTX-treated rats.

${ }^{\mathrm{a}} \mathrm{p}<0.05 ;{ }^{\mathrm{b}} \mathrm{p}<0.05 ;{ }^{\mathrm{c}} \mathrm{p}<0.05$. 
Group A (Control Group). $0.2 \mathrm{ml}$ vehicle alone (98 $\mathrm{mg} \mathrm{NaCl}$, $88 \mathrm{mg} \mathrm{NaOH}$ in $20 \mathrm{ml}$ total volume) was administered intraperitoneally. Sunflower oil was given as a placebo as described below for group B.

Group B (MTX-Treated Group). A single dose $(20 \mathrm{mg} / \mathrm{kg})$ of MTX (MTX $500 \mathrm{mg}$ in $20 \mathrm{ml}$ vehicle, F.H. Faulding \& Co. Ltd., Australia) was administered intraperitoneally to each rat. Sunflower oil $(0.5 \mathrm{ml})$ was given as a placebo through intragastric tube, 3 days before MTX injection, and continued every day till the rats were sacrificed.

Group C (MTX plus VA-Treated Group). Three days prior to administration of a single dose of MTX $(20 \mathrm{mg} / \mathrm{kg})$ intraperitoneally, VA (retinol palmitate, $5,000 \mathrm{IU} / \mathrm{kg}$ dissolved in $0.5 \mathrm{ml}$ sunflower oil) was administered orally through an intragastric tube every day and continued until rats were sacrificed.

The day the MTX injection was given was regarded as day 0 . All the animals were weighed initially and before sacrifice, and the weights were recorded. On the 2nd, 4th and 6th day after injection of MTX, 5 animals of the control group and 8 from each of groups B and $\mathrm{C}$ were sacrificed by intracardiac formalin injection after ether anesthesia. Three tissue samples of jejunum $(0.5 \mathrm{~cm})$ were cut off at a distance of $5 \mathrm{~cm}$ from the proximal end for histopathological examination.

\section{Histopathology}

The tissue samples of the jejunum were fixed by $10 \%$ neutral formalin, embedded in paraffin and cut with a microtome set at a thickness of 5-6 $\mu \mathrm{m}$. The tissue sections were stained with hematoxylin and eosin (HE) and examined with a light microscope. To highlight the goblet cells, the sections were stained for muscin by the periodic acid-Schiff and Alcian blue (PAS-AB) technique, $\mathrm{pH} 2.5$.

HE-stained tissue sections were examined for villus structure and height, histopathological alterations in crypt cells and mononuclear cell infiltration in lamina propria. The appearance of all groups was scored by a single observer (blinded to treatment) as follows: no lesion $=0 ;$ mild damage $=1 ;$ moderate damage $=2$, and severe damage $=3$.

The PAS-AB-stained goblet cells were counted under a $\times 20$ objective in both villi and crypts. For each specimen, a total of 10 microscopic fields of crypts and 10 fields of villi were measured per animal. Goblet cell numbers were scored as 0-49 cells $=3 ; 50-99$ cells $=2 ; 100-149$ cells $=1$, and $\geq 150$ cells $=0$.

\section{Statistical Analysis}

The values are presented as the means $\pm \mathrm{SD}$. In the analysis of both weight loss and histopathologic data, the Mann-Whitney U test was used. For the comparison of the results obtained from the three groups, the Kruskal-Wallis test was applied; $\mathrm{p}<0.05$ was considered to be statistically significant.

\section{Results}

In general the rats in the control group did not lose weight (table 1). However, the rats treated with MTX alone (group B) lost more weight than those treated with MTX plus VA on each sacrificial day. The difference in weight loss between groups $\mathrm{B}$ and $\mathrm{C}$ was statistically significant; the $\mathrm{p}$ values for days 2,4 and 6 were $<0.05$,

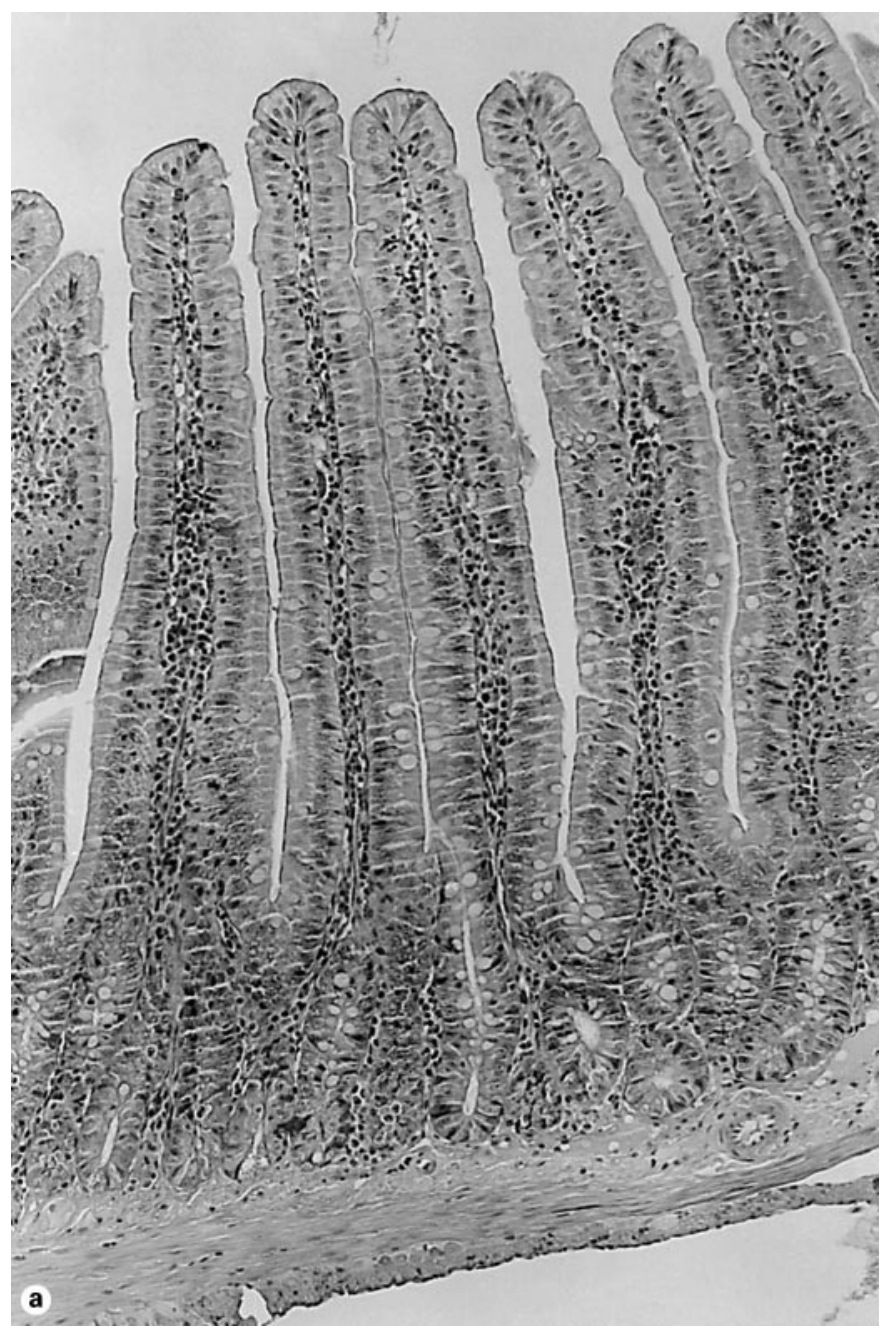

Fig. 1. HE staining of jejunal morphology of rats on day 4 after treatment. a Control group: jejunal histology is normal.

$<0.01$ and $<0.001$, respectively. The rats treated with MTX alone became exhausted and grossly emaciated; 17/ 24 (71\%) developed diarrhea compared to 8/24 (33\%) of the rats treated with MTX plus VA (table 1).

\section{Histopathological Results}

The villus damage, crypt damage, inflammatory cellular infiltration and goblet cell number in the tissue samples from the control and experimental groups are given as total score of intestinal damage in table 2. The tissue sections of the rats in the control group showed normal intestinal structure.

Group B (Treated with MTX Alone). Compared to the control group, the tissue sections of the rats treated with 

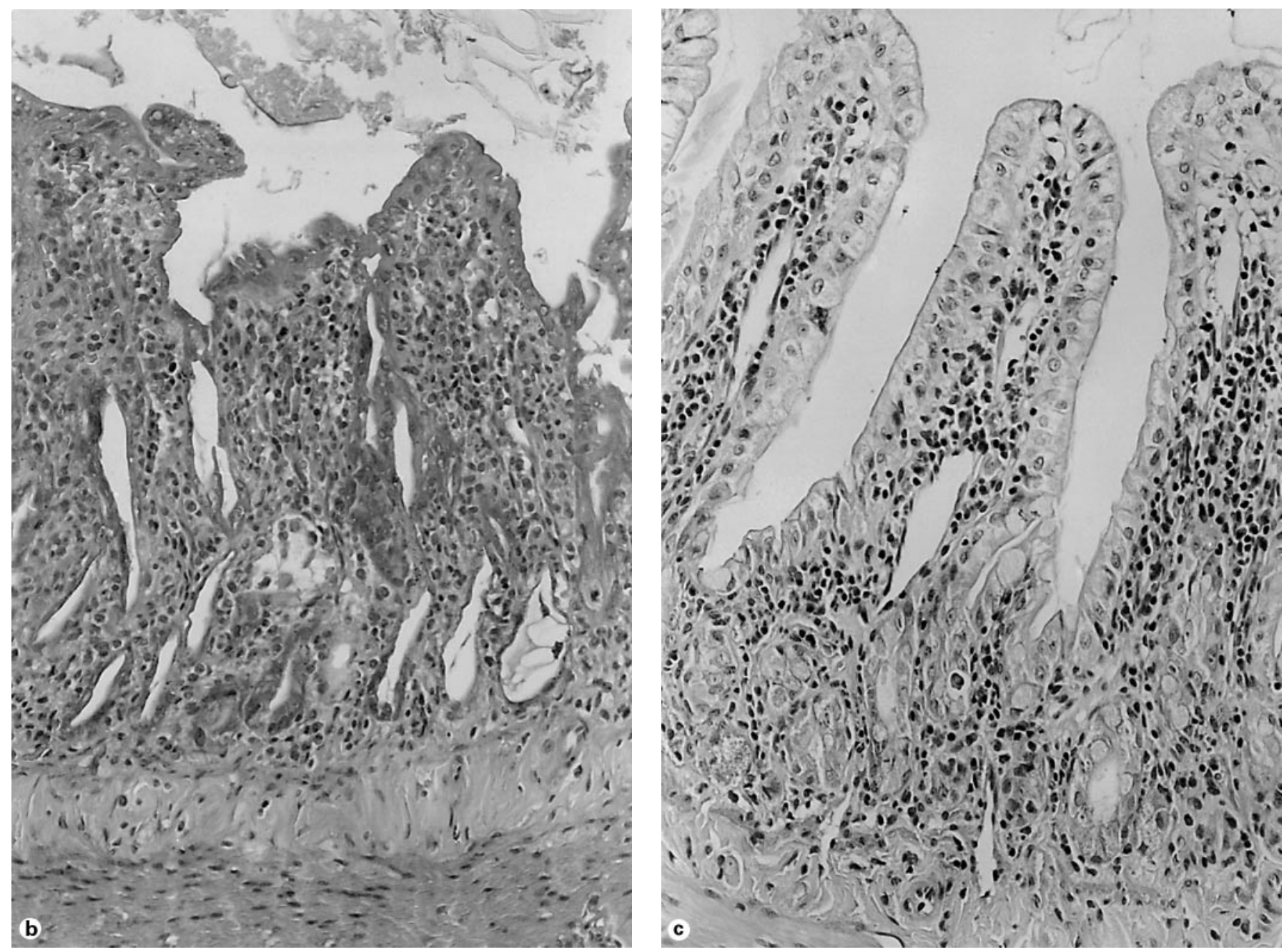

Fig. 1. b MTX-treated group: severe mucosal histological damage (villus shortening and fusion, crypt loss, inflammatory infiltration). c MTX plus VA-treated group: the severity of histological damage was less than that in the MTXtreated group.

MTX alone on day 2 had (a) villus shortening and fusion with variable degrees of epithelial atrophy $(\mathrm{p}<0.01)$, (b) decrease in the number of crypt cells, crypt loss and crypt abscess formation $(\mathrm{p}<0.01)$, (c) inflammatory infiltrate in the lamina propria $(\mathrm{p}<0.05)$, and $(\mathrm{d})$ decrease in goblet cell number in both villi and crypts $(\mathrm{p}<0.01)$. Compared to the rats treated with MTX plus VA, the total score of small intestinal damage on the 2 nd day was significantly higher $(\mathrm{p}<0.05)$. On the 4 th day, there was a clear small intestine damage and the histopathological findings were more severe than those of the 2 nd day (fig. 1). In addition, patchy fibrosis and an increase in vascularization of the lamina propria and cystic dilatation in crypts were seen. Epithelial degeneration was more apparent (dominant).
Goblet cells decreased $(p<0.01)$ and were nearly lost in some areas (fig. 2). By the 6th day, damage to villi and crypts, and inflammatory infiltrate in the lamina propria continued to increase $(\mathrm{p}<0.01)$. Villus height was increased. Despite epithelial cell degeneration, there was also a regeneration increase. The total score of small intestinal damage in the MTX-treated group was higher than that in the MTX plus VA-treated group on the 6th day $(\mathrm{p}<0.05)$.

Group C (Treated with MTX plus VA). The histopathological findings in this group are similar to the findings in rats treated with MTX alone, but the total score of small intestinal damage was less than that of the MTX-treated group for all days $(\mathrm{p}<0.05)$ as outlined in table 2 . 

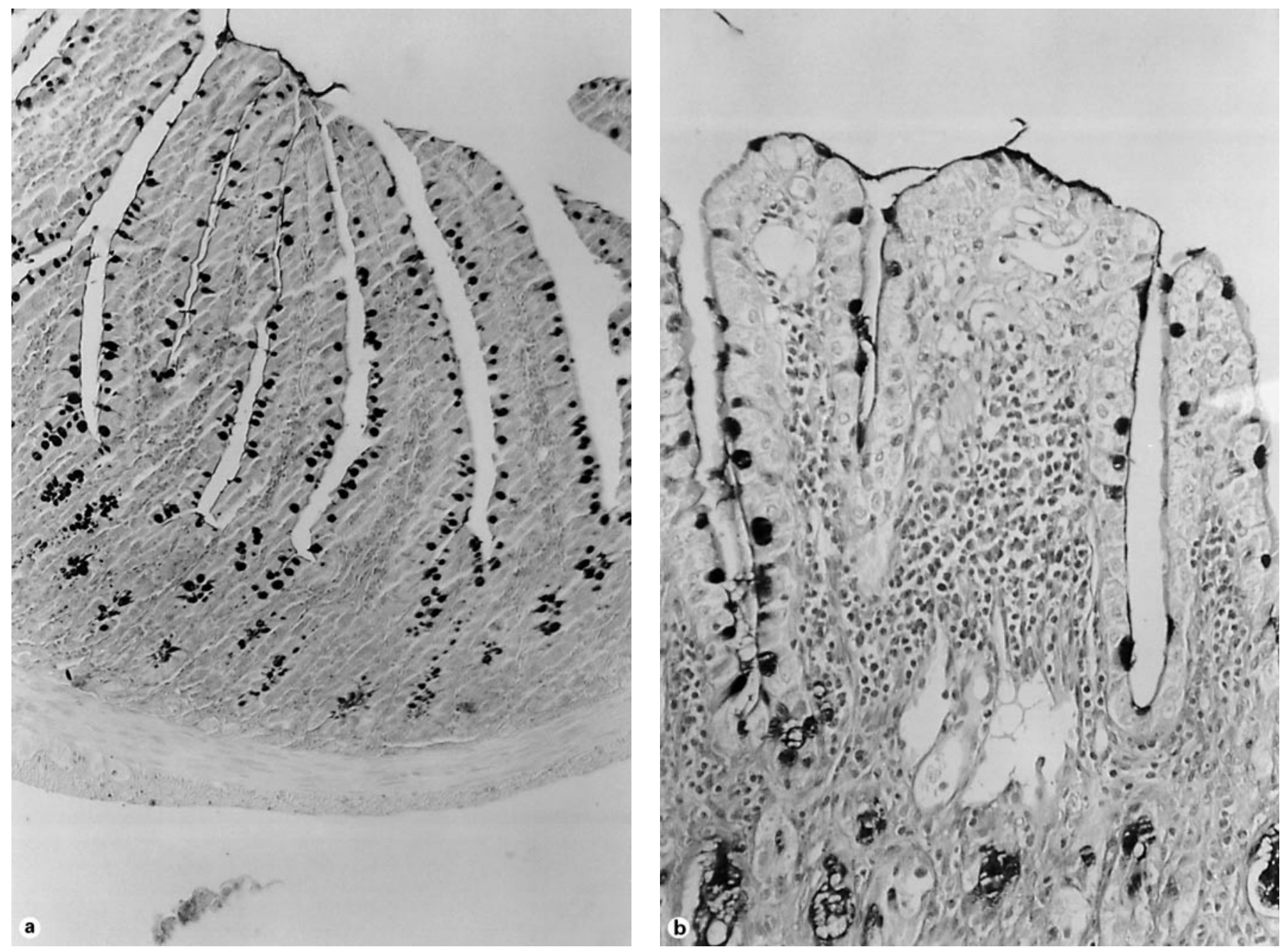

Fig. 2. View of goblet cells of the proximal jejunum on day 4 after treatment. PAS-AB staining. a Control group: normal jejunal histology and goblet cells. b MTX-treated group: apparent goblet cell depletion.

\section{Discussion}

In this study, the general characteristics (villus atrophy, crypt loss, goblet cell depletion) of MTX-induced small intestinal mucositis were the same as described in previous studies $[4,19,20]$. Proliferation of small intestinal epithelial cells occurs in the crypts. Crypt cells, which rapidly regenerate, migrate to the villus tip, and replacement of intestinal epithelium is completed in about 2 days in rats [21], and about 3 days in humans [22] and mice [23] as observed in this study. The MTX-induced damage to the small intestine has been ascribed to the depressed generation of villus epithelial cells, probably due to the damage of the crypt cells, which was deduced by measur- ing the thymidine kinase activity in isolated crypt cells [24].

Retinoic acid receptors are believed to play a crucial role in the regulation of the expression of a variety of growth factors involved in cellular differentiation [16]. VA deficiency results in a decreased expression of transforming growth factor- $\beta_{2}$ (TGF- $\left.\beta_{2}\right)$ in the lamina propria, surface epithelium and crypts of rat intestine, whereas the administration of retinoic acid increases intestinal mucosal TGF- $\beta_{2}$ and TGF- $\beta_{3}$ expression [25]. TGF- $\beta$ has been implicated in the regulation of epithelial growth and differentiation, and intestinal epithelial restitution [26].

A decrease in goblet cell numbers in VA deficiency [15, $27,28]$ and mucin production [27] have also been de- 


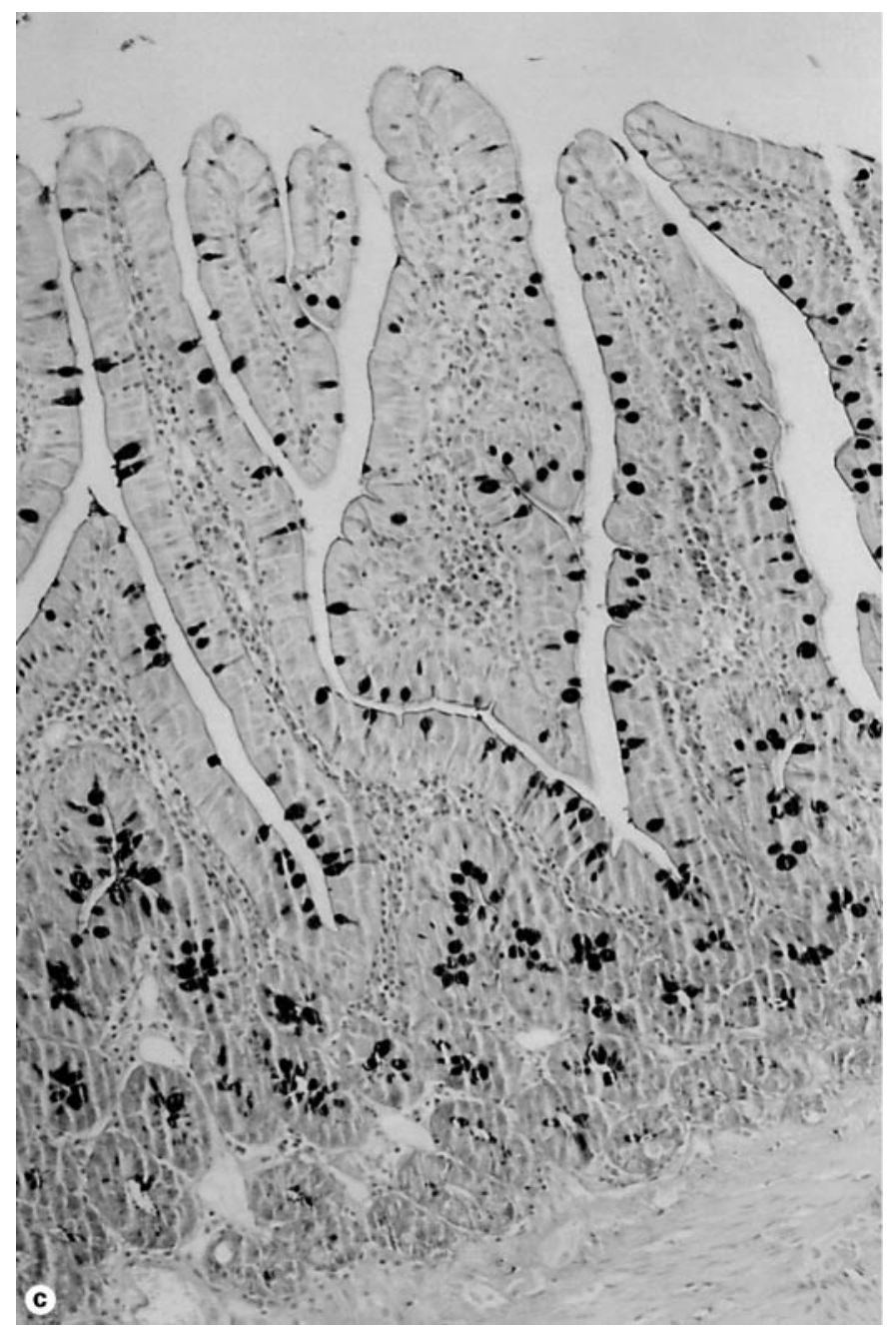

Fig. 2. c MTX plus VA-treated group.

tected. Macromolecular permeability is also increased in VA deficiency [29], indicating a defect in epithelial integrity.

It has been suggested that VA may be involved in the regulation of DNA and RNA synthesis, though the mechanism by which VA stimulates synthesis remains unknown [30]. The present finding that VA protects the small intestine from MTX-induced damage may be explained by the stimulation of DNA and RNA biosynthesis by VA. However, the steps in the pathway of VA-stimulated biosynthesis need to be elucidated for proper interpretation of this protective effect of VA on a molecular level. Furthermore, MTX-induced malabsorption may not be simply a consequence of reduced villus surface area but may also be involved in the interaction of cell toxicity and alteration in villus population dynamics [31]. Since VA contributes to membrane stabilization [30], the protective action of VA may also be related to this epithelial cell membrane-stabilizing effect.

Our results provide histologic evidence that VA administration under the given experimental conditions decreased the MTX-induced damage to the small intestine. Our findings are in agreement with previous studies [8, 17, 18]. MTX inhibits the de novo purine synthesis and the thymidine kinase in the salvage pathway of pyrimidine synthesis in small intestinal crypt cells. Furthermore, it has been reported that VA protects the crypt cells from MTX-induced inhibition of these synthetic activities [17].

It has been reported that diarrhea, caused by MTX or other chemotherapeutic agents that may injure the gastrointestinal tract, may be ameliorated by optimizing the patient's VA status in addition to conventional treatment. Also VA ameliorates MTX-induced malabsorption [32]. The protection is not due to a decrease of MTX bioavailability in the small intestine in the presence of VA, because the MTX plasma concentration was not affected, rather it showed a slight increase with administration of VA [33]. Furthermore, it has been reported that administration of VA did not compromise antitumor activity of MTX both in vitro and in vivo [34, 35]. The amount of VA $(5,000 \mathrm{IU} / \mathrm{kg})$ used in this study has been administered safely in human research [36].

\section{Conclusion}

The findings confirmed that treatment with MTX induced villus shortening and fusion, epithelial atrophy, crypt loss, inflammatory infiltrate in the lamina propria and goblet cell depletion. The administration of VA several days prior to and after treatment with MTX decreased the MTX-induced damage to the small intestine. This protective effect of VA may have clinical applications in cancer chemotherapy. 


\section{References}

1 Gibson RJ, Keefe DM, Thompson FM, Clarke JM, Goland GJ, Cummins AG: Effect of interleukin-11 on ameliorating intestinal damage after methotrexate treatment of breast cancer in rats. Dig Dis Sci 2002;47:2751-2757.

2 Loehry CA, Creamer B: Three-dimensional structure of the rat small intestinal mucosa related to mucosal dynamics in the rat after the administration of methotrexate. Gut 1969;10: 112-116.

3 Taminiau JA, Gall DG, Hamilton JR: Response of the rat small-intestine epithelium to methotrexate. Gut 1980;21:486-492.

4 Naruhashi K, Nadai M, Nakao M, Suzuki N, Nabeshima T, Hasegawa T: Changes in absorptive function of rat intestine injured by methotrexate. Clin Exp Pharmacol Physiol 2000;27: 980-986.

5 Venho VM: Effect of methotrexate on drug absorption from the rat small intestine in situ and in vitro. Acta Pharmacol Toxicol 1976;38: 450-464.

6 Capel ID, Pinnock MH, Williams DC: An in vitro assessment of the effect of cytotoxic drugs upon the intestinal absorption of nutrients in rats. Eur J Cancer 1979;15:127-131.

7 Takeuchi H, Kosakai Y, Tsurui K, Hasegawa $\mathrm{K}$, Horie T, Awazu S: Change in small intestinal brush border membranes of rats following methotrexate administration. Pharmacol Toxicol 1989;65:269-273.

8 Xian CJ, Howarth GS, Mardell CE, Cool JC, Familari M, Read LC, Giraud AS: Temporal changes in TFF3 expression and jejunal morphology during methotrexate-induced damage and repair. Am J Physiol 1999;277:G785G795.

9 Iqbal MP, Sultana F, Mehboobali N, Pervez S: Folinic acid protects against suppression of growth by methotrexate in mice. Biopharm Drug Dispos 2001;22:169-178.

10 Tsurui K, Kosakai Y, Horie T, Awazu S: Vitamin A protects the small intestine from methotrexate-induced damage in rats. J Pharmacol Exp Ther 1990;253:1278-1284.

11 Gao F, Tomitori H, Igarashi K, Horie T: Correlation between methotrexate-induced intestinal damage and decrease in polyamine content. Life Sci 2002;72:669-676.

12 Jaffe N, Frei E, Traggis D, Bishop Y: Adjuvant methotrexate and citrovorum-factor treatment of osteogenic sarcoma. N Engl J Med 1974;291: 994-997.
13 Rosen G, Caparros B, Huvos AG, Kosloff C, Nirenberg A, Cacavio A, Marcove RC, Lane JM, Mehta B, Urban C: Preoperative chemotherapy for osteogenic sarcoma: Selection of postoperative adjuvant chemotherapy based on the response of the primary tumor to preoperative therapy. Cancer 1982;49:1221-1230.

14 Swartz-Basile DA, Rubin DC, Levin MS: Vitamin A status modulates intestinal adaptation after partial small bowel resection. J Parenter Enteral Nutr 2000;24:81-88.

15 Zile M, Bunge EC, DeLuca HF: Effect of vitamin A deficiency on intestinal cell proliferation in the rat. J Nutr 1977; 107:552-560.

16 Warden RA, Strazzari MJ, Dunkley PR, O'Loughlin EV: Vitamin A-deficient rats have only mild changes in jejunal structure and function. J Nutr 1996;126:1817-1826.

17 Kosakai Y, Horie T, Awazu S: Protective effect of vitamin A against the methotrexate-induced damage to small intestine: A study on the crypt cells. Pharmacol Toxicol 1991;69:291-295.

18 Warden RA, Noltorp RS, Francis JL, Dunkley PR, O'Loughlin EV: Vitamin A deficiency exacerbates methotrexate-induced jejunal injury in rats. J Nutr 1997; 127:770-776.

19 Xian CJ, Couper R, Howarth GS, Read LC, Kallincos NC: Increased expression of HGF and c-met in rat small intestine during recovery from methotrexate-induced mucositis. $\mathrm{Br} \mathrm{J}$ Cancer 2000;82:945-952.

20 Taminiau JA, Gall DG, Hamilton JR: Response of the rat small intestine epithelium to methotrexate. Gut 1980;21:486-492.

21 Messier B, Leblond CP: Cell proliferation and migration as revealed by radioautography after injection of thymidine- $\mathrm{H}^{3}$ into male rats and mice. Am J Anat 1960;106:247-285.

22 Lipkin M, Sherlock P, Bell B: Cell proliferation kinetics in the gastrointestinal tract of man. II. Cell renewal in stomach, ileum, colon and rectum. Gastroenterology 1963;45:721-729.

23 Leblond CP, Messier B: Renewal of chief cells and goblet cells in the small intestine as shown by radioautography after injection of thymidine- $\mathrm{H}^{3}$ into mice. Anat Rec 1958;132:247259.

24 Chu E, Mota AC, Fogarasi MC: Antimetabolites; in DeVito VT, Hellman S, Rosenberg SA (eds): Cancer, Principles and Practice of Oncology, ed 6. Philadelphia, Lippincott, Williams \& Wilkins, 2001, pp 388-393.
25 Glick AB, McClune BK, Abdulkarem N, Flanders KC, Lumadue JA, Smith JM, Sporn MB Complex regulation of TGF $\beta$ expression by retinoic acid in the vitamin A-deficient rat. Development 1991;111:1081-1086.

26 Dignass AU, Podolsky DK: Cytokine modulation of intestinal epithelial restitution: Central role of transforming growth factor $\beta$. Gastroenterology 1993; 105:1323-1332.

27 Ahmed F, Jones DB, Jackson AA: The interaction of vitamin A deficiency and rotavirus infection in the mouse. Br J Nutr 1990;63:363373.

28 Rojanapo W, Lamb AJ, Olson JA: The prevalence, metabolism and migration of goblet cells in rat intestine following the induction of rapid, synchronous vitamin A deficiency. J Nutr 1980;110:178-188.

29 Gimoshinskii IV, Khvylia SI, Kon II: Effect of vitamin A deficiency on permeability of the small intestine mucosa for macromolecules in adult rats. Bull Exp Biol Med 1987;103:179_ 182.

30 Lotan R: Effects of vitamin A and its analogs (retinoids) on normal and neoplastic cells. Biochim Biophys Acta 1980;605:33-91.

31 Pinkerton CR, Milla PJ: Methotrexate enterotoxicity: Influence of drug dose and timing in the rat. Br J Cancer 1984;49:97-101.

32 Yamamoto JI, Horie T, Awazu S: Amelioration of methotrexate-induced malabsorption by vitamin A. Cancer Chemother Pharmacol 1997; 39:239-244.

33 Tsurui K, Kosakai Y, Horie T, Awazu S: Vitamin A protects the small intestine from methotrexate-induced damage in rats. J Pharmacol Exp Ther 1990;253:1278-1284.

34 Nagai Y, Horie T, Awazu S: Vitamin A, a useful biochemical modulator capable of preventing intestinal damage during methotrexate treatment. Pharmacol Toxicol 1993;73:69-74.

35 Yamamoto J, Nagai Y, Horie T, Awazu S: Effect of vitamin A on the methotrexate cytotoxicity in L1210 murine leukemia cells in culture. Cancer Chemother Pharmacol 1993;32: 263-267.

36 Marcus R, Coulston AM: Fat-soluble vitamins; in Hardman JG, Limbird LE, Gilman AG (eds): The Pharmacological Basic of Therapeutics, ed 10. New York, McGraw-Hill, 2001, pp 1773-1783. 